\title{
To the Issue of the Russian Impressionism in the 1960s
}

\author{
Lyubov Shirshova \\ Russian State Specialized Academy of Arts \\ Russian Academy of Arts \\ 21 Prechistenka street, Moscow, 119034, Russia \\ E-mail: lshirshova@rah.ru
}

\begin{abstract}
The article reveals the origins of creativity of the People's Artist of the USSR, Academician of the Russian Academy of Arts Efrem I. Zverkov as an artist - impressionist. It also expands the range of ideas about the creative activity of the master and shows new aspects of his landscape painting of the 1950's and 1960's.
\end{abstract}

Keywords - art of the "thaw" period; time of changes; Russian impressionism of the 1960's; traditions in art; a study from nature; national landscape painting

\section{INTRODUCTION}

The beginning of the 21st century is characterized by considerable attention to the art of the famous "thaw" period that took place during Khrushchev's time. Understanding of the artistic experience of the "Sixtiers" is facilitated by largescale exhibitions at the State Tretyakov Gallery, State Russian Museum, at many other public and private museums in Russia, by new museums devoted to creative work of V.I. Ivanov in Ryazan and E.I. Zverkov in Tver, and also by events at the Museum of Russian Impressionism and the Institute of Russian Realist Art in Moscow. Work of "Sixtiers" is an artistic and cultural historical phenomenon with its own history and evolution. In mid-20th century, they courageously stepped into the proscenium of artistic life and brought forward the national art to new horizons. Their creative momentum has become fundamental for art development in Russia for decades that followed. Attention to the heritage of "Sixtiers" as to a unique, critical, and incredibly significant artistic phenomenon is an important trend in the national science of recent years. A wider research spectrum of the art subjects created in the 19501960 s contributes to our more accurate system of values in the complicated picture of the age of changes. The "Sixtiers", who made new art in theater, fine arts, literature, music and cinema, have become symbols of the time and a kind of a window into the infinite space of the national culture.

Usually, the 1960s are associated with the art movement that had a characteristic journalistic trend started by artists belonging to the "OST" (Russian: OCT) society and the "Diamonds Jack" society (Russian: Bubnovyi Valet), the movement, that later A. Kamenskyi, a fine art expert, would call "the harsh style". However, the evolution of the art of the 1960s had not been limited by the "harsh style". Among the new generation of artists had been those who pursued different artistic aims and those aims were associated with the development of the Russian impressionism and traditions of masters from "The Union of Russian artists". The impressionism, where a painter can show his personality and his world's vision has become a symbol of creative freedom. Young painters, mainly graduates of the Surikov Moscow Art Institute, professionally bred in the classical, academic traditions. Upon fundamentals of the Moscow school of painting, they have synthesized the artistic experience of the past generations and pioneer findings of new times in their works. E.I. Zverkov had become one of the leaders of that direction. His works of the 1950-1960s had features of a different pictorial vision, which exerted influence on the development of the landscape of the Moscow school of painting and on the Russian Impressionism. In his art, the landscape painting had been the result of a joining of various stylistic tendencies. In his landscapes-situations, we find the synthesis of national, realistic art, impressionism, romanticism and symbolism. E. I. Zverkov was a vivid personality in all respects: in his art, in his social activity, in his art of persuading, and in his admiring the talents of contemporaries. Rethinking the principles of impressionist painting, he experimented a lot, captivating others with the creative spirit of the time, realizing perfectly well that new artistic situation creates a basis for freer self-expression.

Even though the name of E. I. Zverkov, a People's Artist of the USSR, a member of the Painting Academia and a winner of State Prizes, has been introduced in the Annals of Art History long ago, and his paintings are well represented in the State Tretyakov Gallery, State Russian Museum, in more than 50 museums in Russia, and in foreign collections, but the art of Master has not yet been sufficiently studied. At present, only general information can be drawn from various publications. There are no special dedicated studies up to date. The present article is only an attempt to identify the origins of Zverkov's artistic practice as an artistimpressionist.

\section{PERIOD OF STUDY}

The fundamentals of artistic literacy were taught to Zverkov's in Tver by N.Ya. Borisov, a graduate of the Imperial Academy of Arts, who in turn had got his mastery from such great teachers of the Russian school as P.P. 
Chistyakov and I.E. Repin. Zverkov's inclusion into the Moscow school of painting began in 1946 at the Moscow studio for front-line soldier artists. He was enrolled at the B.V. Ioganson workshop by competition selection. The importance of this studio in the artist's fate is hard to overestimate. B.V. Ioganson was a bright and creative person, and his teacher, K. A. Korovin, was his ideal Master of Art who had actually begun the history of the Russian Impressionism. Ioganson based his teaching practice (recalling his mentor) on a method of emotional comprehension of natural harmony, and made his disciples strive for the wholeness of the vision of the entire system of color and tonality. He enriched his studio students with his opinion, his professional knowledge, his human qualities, and promoted the development of their world view. At the end of the first year of training, Zverkov' began to distinguish himself out of the student community as a fine colorist with the gift of a compositional architecture of his works; he drew the attention of Ioganson, who highly praised the Zverkov's ably painted class work, "The Gypsy" (1946). Still in his study days, Zverkov begins to work actively in the style of Russian impressionism. This helped to form a careful attitude to the nature, which became the basis of the master's style. During those years, he has been actively studying the museums' collections and attending exhibitions of his contemporaries.

The Zverkov's acquaintance with A.A.Plastov took place in 1947 in Moscow. It was an important event that later developed into a true friendship with a significant impact on the young artist's personality. When studying at the Moscow State Art Institute (1947-1953) and in the 1950s, Zverkov painted large compositions in traditions of realistic art enriched by impressionistic findings. As far back as his student years, Zverkov already tried to find acute compositional solutions to aggregate the forms and have a fresh, etude-like color solution. At that time, the outstanding masters - I.E. Grabar and S.V. Gerasimov - taught at the Institute. A special spiritual liaison existed between Zverkov and the eminent Masters, P.P. Konchalovsky, A.A. Dejneka, Yu.I. Pimenov, V.A. Favorskyi and others, who created a high level of artistic environment - their creative ideas had a great impact on the youth.

In the late 1940s - early 1950s, it was a complicated period in the history of national art: the campaign of 1947 against the "rootless cosmopolitans"; the dissolution of the Museum of New Western Art in 1948 and the dismissal of the outstanding painter, S.V. Gerasimov, from the position of the rector of the Surikov Moscow Art Institute; a war waged against "impressionists", "formalists" and so on. The events also affected Zverkov, who was one of the best students; he had been asked to abandon a previously selected topic of his diploma and take a composition on the life and activities of I.V. Stalin. The situation had become quite critical. Zverkov insisted on the earlier chosen topic, and it was a deliberate creative act. At the invitation of A.A. Plastov, E. I. Zverkov left in order to paint his diploma work to Prisloniha village, the Ulyanovsk Region. During that period, the young artist was thrilled by the problems of plein-air impressionist painting. The subject of the diploma had not been approved by the Institute's Scientific Council, and it was called "Children's radio program". The focus of the young artist's attention was not so much the development of the painting plot (a warm summer day, in a room filled with sunlight and air streaming from the open windows, and children sitting at and standing around the table with a radio-set on, listening to a children's radio program), but rather the plein-air development. The artist creates a lyrical, emotionally loaded painting that combines the genre of portrait, still life, and the scenery outside, behind the window. The artist's personal identification went on very actively. A.A. Plastov was a wise mentor; he spoke with his diploma student about the latter attitude towards the creative work, the mission of the painter, and the basics of the artistic perception of the outside world. However, with the immense respect towards his great mentor, Zverkov was taking the latter's creative experience selectively, seeking his own way in the art.

\section{CREATIVE WORK}

In the first half of the 1950s, Zverkov, much like many of his contemporaries, turned his attention to the storyline genre which included: "On way to work in a kolkhoz" (1953), "Back from a business trip" (1956), and "Breakfast in the fields" (1960). This period is the most important benchmark in the artist's personal identification. In his paintings of rural life, he sought to convey the depicted truthfully; however, he wanted to escape literariness and descriptiveness but rather to express a poetic vision of reality. During those years, the artist worked in various genres, painted portraits, stills and landscapes. It is important to note that in the thematic paintings by Zverkov, the landscape, as such, had never been a background, but rather it was natural environment for the characters of the opus. Coming into contact with daily routine, the painter, with his powerful landscape perception, built on the philosophical essence of the nature's image. The landscape painting techniques raised an emotional origin; they deepened semantic and imaginary content, making the associativity of his works deeper and contributing to a significant clarity in the color palette. Zverkov's early landscapes are notable for vivid and saturated coloration. However, in the late 1950-s, a more complicated silver and blue gamma appeared in his works.

E. I. Zverkov went on developing the line of the Russian lyrical landscape in his work. The artist's attitude to nature is a specific life philosophy. A front-line soldier during the Great Patriotic War, he had experienced many shocks and met with the tragedy of the loss in the years of war. It was in spite of the destruction and death that he had treasured a pure sacral attitude to the highest values on Earth, to life and to nature, being the attitude he professed throughout his life. Nature for him was a temple, originating lofty feelings in man. "Nature, I think", the artist used to say, "plays a decisive role in shaping of an individual". "I want to draw attention to it, to encourage people to fall in love with the Beauty" [1, p. 54].

An art researcher, V. Filippov, in determining the peculiar features of the Russian Impressionism, stated its characteristics: kinship with realism close to method associated with the nature vision; content-richness of the 
pictorial image; ability to reflect the condition of the fastchanging Russian soul; the artist's feelings, and finally, the predominance of the painting sketch, as well as the "village disposition" of paintings [2, p. 6].

In art, in creation of a new artistic reality, Zverkov had always aspired for a harmonious connection of deeply personal conceptions with the everlasting and immortal things. The enhancement of the artist personality found its expression in his paintings. He often turned to the spring and autumn landscapes with associations with the eternal circular flow of life on Earth, with time of birth, awakening, and extinction of the nature and human life. As an impressionist, he recognized the value of the seemingly ordinary moods of nature in their eternal uniqueness. However, in his landscapes, he had longed for consolidation of the nature's image. The color for him had been a visual embodiment of the world, of the light itself, of the sun and air. He had been experimenting trying to increase the expressiveness of the landscape image. By leaving only 3-4 colors on the palette, he painted a landscape with large spots of paint accompanied with subtle coloristic development within its borders, exposing the tonal wealth and the incredible plurality of the color shades inside the spot (Beginning of spring of 1953). He painted his pieces close by the tone; they were almost monochromatic ("A monastery", Pereslavl - Zalesskij, 1957). He found a new color quality to paint a shade that acquired special beauty and coloristic expressiveness ("A street in winter". 1954). He seeks to fully expose the effects of the light and air environment upon subjects and tonal coloring. The skies had become a special area of development. A young artist investigates the structure of clouds, the movement of air currents, and the emergence of thunderstorm clouds. Continuous systematic work in the plein-air had contributed to a deep personal understanding of the landscape aesthetic content, to the achievement of excellence in rendering the richest shades of the light environment, and to the ability to convey the finest emotional impressions of the landscape scene. At that time, in Zverkov's landscapes emerged a certain range of images: autumn fields and country roads, field woodlands and small villages, meandering streams, overgrown with shrubs and birch groves. His village landscapes were almost always desolate.

From 1957 until the early 1960s during summer and sometimes in winter, E. I. Zverkov used to work at the Art center named after D.N. Kardovsky in the old town of Pereslavl Zalessky. In all those years, he arrived there as an artistic leader of artists groups or "streams", as they were then called. Having demonstrated extraordinary teaching abilities, the master evolved into an attentive mentor for many young painters from various parts of the country. The sense of purpose, energy and uniqueness of his imaginative and plastic language, the light-bearing painting craft - all that had influenced without any doubt upon the art of many young artists, promoting their fruitful quests. As he progressed in portraying nature, Zverkov always used to paint a lot, carefully analyzing it and exploring. Multiple sketches of landscape motifs helped him to better analyze spatial relationships, to understand the shape of trees, the outlines of the shores of a river and of a faraway village on the hill. During that time, he had a special passion for watercolor techniques. Watercolor painting contributed to gradual complication of chromatic system, to discovery of inexhaustible richness of nuances and shades, and production of a transparent, gentle musical touch. A careful study of nature, to convey an immediate sensation from a natural phenomenon that caught one's imagination, was a crucial stage in the development of Zverkov's art. Due to the exquisite color gamma, his paintings were full of light and elegiac in mood. Although very talented, the exhausting and painstaking daily work had become the basis for the comprehension of the mysterious and diverse life of nature.

The impressionistic way of Zverkov's vision is a tool for individual search for new techniques of artistic expressiveness, the embodiment of the artist picture of the world perception. The canvas "Autumn" (1955) was a conclusive testimony to the new creative abilities of the artist Complex, finely nuanced coloration of the painting landscape acquired an emotional depth and, color based on interaction and dominance of ocher, warm tones, mildly conveying the infinity of the shades of autumn, revealed the condition. In each colorful touch, something precious did appear, and the color began to sparkle and flicker on the canvas surface.

The evolution of Zverkov's creative work reveals a series of gradual changes in both his artistic practices and his imaginative characteristics. During the 1940s to the 1990s, the artist worked hard in plein air in localities near Moscow, Tver and in the Russian North.

While traveling to the Russian North, a brand new qualitative phase came to Zverkov's creative work. It is important to note that: in the 1950s, the artist paid special attention to storyline compositions, but starting from the 1960 s, he had turned essentially to landscape painting. Zverkov considered the North as the source of the national culture and a land of primeval nature with vast river floods, endless forests and eternal skies. The painter plunges into that majestic eternity of northern nature. In his works, grandeur and vastness of the painter's artistic thinking emerge. He created a collection of landscapes that differed from his earlier works by expansion of the plastic range, by alternative emotional fullness. The landscapes of the $1960 \mathrm{~s}$ and 1970s differed in execution techniques. They were painted with isolated, multicolored strokes. Zverkov started his work on this new landscape, both with the understanding of the spatial relationships and patterns and with the graphical search for forms and linear rhythms in the spatial system plans. Counterpoint in his perception of image of the North is quite obvious. He addressed the topic of spiritual memory and creates landscapes depicting small streets of an old town of Kargopol with white-stone temples. He painted whole series of village landscapes, creating an image of a historical space that preserves the visible memory of the lifestyle pattern of many peasant generations. Most of all, he liked painting the deeply reserved life of the North nature. In romantic and epic landscapes of primeval nature, Zverkov sought uniting his perception of modern age with a bright emotional and poetic world perception. For a painter, his 
creative work meant depicting on his canvas the world that reflected his spiritual condition. We see in his works, a quest for perfection, harmony, stately simplicity, and for special, lucid, exalted silence. His landscapes of that period were the paintings that were notable for nobility and subtlety in coloration that transforms an ordinary motif into a unique natural phenomenon. The painter's style had been formed from the affirmation of the importance, poetry, and beauty of the surrounding world. He had been able to reconsider the impressionist roots and unite them with the national tradition of the "landscape of the mood", to create a deeply original arsenal of the fine art means. To a large extent, Zverkov considered the impressionist issues of a truthful transfer of the light and air environment as a possibility to enrich the painting with new artistic method and technical know-how. In his landscapes, he used the beauty of the impressionist moment images to create generalized paintings of the Russian nature with exquisite prowess ("Northern Spring", "Spring flood" and others). A kind of fusion occurred in the construction of a color-plastic structure and in the organization of the canvas plane. In the master's understanding, the form, image, volume, color, tone, and plastic of the stroke, all that were parts of one single entity, were aimed at exposing the world perception of the painter and at poetic understanding of nature. He always set new color tasks and solved them perfectly, perceiving his coloration and understanding his visual and expressive tools. His paintings were built upon complicated color and light ratios.

\section{CONCLUSION}

The second half of 1950s and early 1960s were, for the artist, the time of acquisition of his own creative image. During those years, a special conventionality is created for the artistic language of the master's works, based on a deep knowledge of the pictorial laws of visual arts. A poetic conventionality and a color metaphor in Zverkov's creativity are multisided notions; they were expressed not only in the amount of pictorial and plastic techniques reflecting the emotional projection of the subject world, but also in the peculiarity of the artist's creative thinking, who perceives specifics of phenomena and images of reality as a family of poetry associations. By embodying his personal perception of the nature and environment, he had shaped in himself a very individual artistic style.

In a line of masters of Fine Arts, who changed the aesthetic beliefs of the society in the 1950-1960s and who developed the traditions of the Russian Impressionism in their works, a special place belongs to Efrem Ivanovich Zverkov. His work presents an extremely important contribution in the framework of the universal quest for a national identity in the art.

\section{REFERENCES}

[1] Nikulina O.R. Nature in an artist's eyes: Problems of development of present-day landscape painting - M.: Soviet Painter, 1982. - M., 1982. - 175 p.; fig 21.

[2] Filippov V. impressionism in the Russian painting - M.: Belyi gorod, 2001. - 320 p. 